Article

\title{
Does a Firm's Corporate Governance Enhance the Beneficial Effect of IFRS Adoption?
}

\author{
Jaeyon Chu ${ }^{1}$, Kyongsun $\mathrm{Heo}^{2, *}$ and Jinhan Pae ${ }^{3}$ (D) \\ 1 Department of Accounting, Hannam University, Daejeon 34430, Korea; jychu622@hnu.kr \\ 2 Department of Global Business, Kangnam University, Yongin-si 16979, Korea \\ 3 Business School, Korea University, Seoul 02841, Korea; jinhanpae@korea.ac.kr \\ * Correspondence: kyongsun.heo@kangnam.ac.kr; Tel.: +82-31-280-3738
}

Received: 13 January 2019; Accepted: 6 February 2019; Published: 8 February 2019

\begin{abstract}
Prior literature suggests that the effect of adopting the International Financial Reporting Standards (IFRS) could vary by country-specific or firm-specific factors. In particular, we focus on the effect of the strength of corporate governance of a firm, a firm-specific characteristic, prior to the adoption of IFRS. Specifically, we use the Korea Corporate Governance Stock Price Index, a metric for the corporate governance structure in Korea, to examine whether the corporate governance structure influences the effect of IFRS adoption on the analyst's earnings forecasts in Korea. We find that the beneficial effect of IFRS adoption on analyst forecast errors is observed for firms with moderate corporate governance prior to IFRS adoption, but not for firms with superior or inferior corporate governance. We interpret our findings such that firms with strong or weak corporate governance do not benefit from IFRS adoption, because firms with strong corporate governance already had transparent information system prior to IFRS adoption and firms with weak corporate governance failed to implement IFRS properly.
\end{abstract}

Keywords: International Financial Reporting Standards; analysts' absolute forecast errors; corporate governance; Korea Corporate Governance Stock Price Index

\section{Introduction}

The demand for a single set of internationally accepted accounting standards led to the adoption of the International Financial Reporting Standards (IFRS) by the member countries of the European Union and many other countries around the world, which also reflect the growing flow of globalization. Although regulators have claimed that IFRS adoption will be beneficial to investors and companies, there are still ongoing debates about the effect of IFRS. Proponents of IFRS claim that a single set of the global accounting standard enhances financial statement comparability and provides more value relevant numbers [1]. It is also claimed that IFRS will facilitate an efficient functioning of the capital markets [2]. On the other hand, opponents argue that a transition to IFRS is costly, and the "one size fits all" IFRS fails to reflect economic conditions of companies in different countries.

In this context, the expected benefits of IFRS adoption can be questioned. Recent studies point out that the effect of IFRS adoption differs according to the firm-specific or country-specific factors [3-6]. In this study, we examine whether IFRS adoption improves the information environment and whether the effect of IFRS adoption varies with firm-specific corporate governance structure in Korea. We find that a beneficial effect of IFRS adoption on analyst forecast errors is observed for firms with moderate corporate governance prior to IFRS adoption, but not firms with superior or inferior corporate governance.

As IFRS adoption is an important financial reporting reform in recent years, a lot of researchers have examined the impact of IFRS adoption [7-11]. Most extant studies generally find that analysts' 
forecasts and the financial reporting quality have improved after the adoption of IFRS [1,12-16]. It is also reported that the alleged benefits of IFRS adoption will be realized only when suitable enforcement or implementation mechanism is present $[5,9]$. This suggests that any benefits from IFRS could be different across countries with different legal regime, the maturity of the capital market, etc. In addition, firm-specific factors such as the level of financial reporting transparency could influence the effect of IFRS adoption. Noting that corporate governance influences the transparency of financial reporting, we examine whether the effect of IFRS adoption on analysts' forecast errors differs depending on the strength of corporate governance.

We conducted empirical analyses using a sample of Korean listed companies over the period from 2007 to 2012. First, consistent with prior studies, we find that analysts' forecast errors decreased in the post-IFRS period, suggesting that IFRS adoption reduces information asymmetry. Second, we find that the effect of IFRS adoption varies according to the strength of corporate governance. The decrease of analyst forecast errors is observed for firms with moderate corporate governance, but not for firms with superior or inferior corporate governance. We interpret these findings as follows. When firms already had strong corporate governance prior to IFRS adoption, the benefits of IFRS adoption are limited because the firms' financial reporting was already transparent due to strong corporate governance. On the other hand, to the extent that firms with weak corporate governance fail to implement IFRS properly, we contend that the benefits of IFRS would not be materialized. Our results suggest that the beneficial effects of IFRS adoption depend on the strength of firm-specific corporate governance in the pre-IFRS period.

This paper contributes to the literature in the following ways. First, unlike prior studies that focus on developed capital markets, we shed light on the effect of IFRS adoption in the emerging capital markets of Korea. Second, unlike other studies examining the effect of IFRS adoption across countries, we consider a firm-specific characteristic, corporate governance, within a country. We emphasize that the effect of IFRS adoption on the information environment depends on the firm-specific factors as well as country-specific factors.

Sustainability in the economic domain is a comprehensive method that management of firms employ to maximize long-term economic value. In this paper, we argue that the alleged benefits of IFRS adoption will be realized only when a suitable enforcement mechanism is present. Even though the global accounting standards improve financial statement comparability and provide more value relevant information, firms need to have a solid management framework to realize the expected benefits. Good corporate governance enables firms to better manage environmental risks to create long-term value for shareholders. Thus, sound corporate governance is a prerequisite to stimulate the sustainable growth of the business.

The remainder of the paper is organized as follows. The next section develops empirical hypotheses and Section 3 explains the research design. Section 4 describes data and descriptive statistics, and Section 5 presents the results. In Section 6, we provide a summary and concluding remarks.

\section{Hypothesis Development}

\subsection{Korea Corporate Governance Index}

In the middle of the 1990s, East Asian countries confronted a financial crisis due to currency devaluation and the stock market bubble. Like other East Asian countries, South Korea could not avoid the financial crisis. The crisis was attributed in part to weak corporate governance $[17,18]$. Thus, Korea's government started a series of reforms to improve corporate governance.

The Korea Corporate Governance Service (KCGS), which was established in 2002, started to survey the corporate governance structure of Korean firms listed on the Korea Exchange. Since 2003, KCGS has released the Korea Corporate Governance Stock Price Index (KCGI). The KCGI aims to provide investors with information about corporate governance of a firm and to induce firms to improve corporate governance and financial reporting transparency. The KCGI will help investors 
make appropriate investment decisions by providing information about whether companies have adequate corporate governance in place or not.

KCGS evaluates the firms' governance structure based on five categories; Shareholder Rights, Board of Directors, Disclosure, Audit Committee, and Ownership Parity.

First, the Shareholder Rights' category pertains to the ownership structure. According to the La Porta, Lopez-De-Silanes, Shleifer, and Vishny (2000) and Johnson, La Porta, Lopez-De-Silanes, and Shleifer (2000) $[19,20]$. Large shareholders use their power to exploit minority shareholders for their own benefits, detrimental to firm value. 'Shareholder Rights' assesses whether the firm has sound corporate governance structure. Second, the 'Board of Directors' category evaluates whether firms have an independent board, outside directors, compensation committee, and so on. Third, the 'Disclosure' category considers the contents of annual and interim reports, investor relations, and other disclosure activities. Fourth, the 'Audit Committee' category regards the composition and quality of the audit committee. Lastly, the 'Ownership Parity' assesses whether every shareholder has the equal right regardless of their ownership size.

\subsection{Background of International Financial Reporting Standards (IFRS) Adoption in Korea}

With globalization spreading rapidly, there has been a growing demand for an internationally acceptable set of high quality financial reporting standards in 2000s. The International Organization of Securities Commissions prompted world-wide regulators to permit using a single set of accounting standards across countries. They claim that the adoption of the IFRS improves firms' information environment and increases financial reporting comparability. In 2005, the European Union member countries, Australia and New Zealand simultaneously mandated all publicly listed companies to adopt the IFRS. Now, 129 jurisdictions have already adopted or have made a public commitment to the IFRS for their publicly accountable companies such as listed companies and financial institutions.

Proponents of the IFRS adoption claim that they have advantages for several reasons. First, compared to the traditional rules-based standards, IFRS is principles-based. Therefore, the IFRS constrains managerial discretion such as abusing allowable accounting alternatives. Second, the IFRS imposes more extensive disclosure requirements so that firms disclose more information than they did under the local Generally Accepted Accounting Principles (GAAP). Third, IFRS enhances the comparability of financial reports across countries. To the extent that IFRS enhances the transparency of financial reporting and the volume of disclosure, we expect that IFRS adoption reduces agency costs and enhances the efficiency of business decision makings. On the other hand, financial reporting quality could deteriorate due to increasing managerial flexibility under IFRS. The companies could abuse their discretion over the choice of accounting methods and estimates, which is inherent under principles-based accounting standards like the IFRS. Thus, the adoption of IFRS can either enhance information environment or deteriorate information environment.

Extant studies report mixed results for the effect of IFRS adoption on the information environment. On the one hand, several studies point out that "one size fits all" IFRS could lower financial reporting quality. As the IFRS reduces alternative accounting choices, it might be less reflective of companies' economic position and performance. Furthermore, domestic accounting standards had been used for a long time so that it may better represent financial condition and performance of firms in a true and faithful manner. In this view, accounting information under IFRS could be less useful to decision makers. In the similar vein, Daske (2006) reports that analysts report less accurate and more dispersed forecasts when they follow German firms which adopt IFRS (IAS) [21].

On the other hand, most extant studies report that the information environment improves after the adoption of IFRS [9,12,14-16,22,23]. Moreover, Barth, Landsman, and Lang (2008) find that firms applying IFRS are generally engaged in less earnings management, recognize earnings on a timelier basis, and provide more value relevant accounting numbers [1]. These prior studies explain that IFRS adoption improves the information environment by enhancing transparency, comparability, and earnings quality. 
The Korean Accounting Standards Board (KASB), the accounting regulatory body in Korea, made a commitment to IFRS in 2007. KASB required publicly listed companies and financial institutions to adopt the IFRS in 2011. Furthermore, large firms with assets of 2 trillion won or above (approximately US 2 billion dollars) were required to disclose consolidated financial statements in the interim periods; however, the requirement was waived for small and medium-sized firms until 2013.

The effect of IFRS adoption on analyst forecast accuracy will not be universal across countries because the effects of IFRS adoption on the information environment would be influenced by country and firm-specific factors [3-5]. For example, Kvaal and Nobes (2010) showed that the implications of IFRS adoption vary depending on country specific factors such as accounting standards, enforcing regime, and the maturity of their economy (developed or developing) [4].

Korea has different regulatory and institutional features compared to European and other countries. As a result, the effect of IFRS adoption on information environment could differ in Korea for the following reasons. First, all public Korean companies were mandated to adopt IFRS. In the case of the European Union (EU), there was an exemption for some publicly listed firms [16]. Second, European and other countries have published consolidated financial statements as the primary financial statements in the pre-IFRS period, but Korean companies disclosed non-consolidated financial statements as the primary financial statements before the adoption of the IFRS. However, even in the pre-IFRS period when non-consolidated or separate financial statements were the primary financial statements, firms attached consolidated financial statements as supplementary financial statements with a delay. Thus, a transition to the IFRS caused difficulties and complexity to users of financial statements, even to sophisticated users such as financial analysts.

For Korean public companies, we predict that analysts' forecast accuracy improves in the postIFRS period. Even though there are a few studies documenting a deterioration of the information environment after IFRS adoption in part due to difficulties when analysts interpret IFRS financial statements, most studies report an improvement of the analyst information environment. Thus, our first hypothesis is:

Hypothesis 1. The adoption of the IFRS improves analysts' forecast accuracy.

Next, we examine whether the effects of IFRS adoption on the information environment vary with the firm-specific factors. The adoption effect is likely to be influenced by country and firm-specific factors [3-5]. For instance, Byard, $\mathrm{Li}$, and $\mathrm{Yu}$ (2010) assert that differences in enforcement regimes across countries could influence the effect of IFRS adoption [9]. They find that improvements of analysts' forecast accuracy for mandatory IFRS adopters are more pronounced in strong enforcement regimes than in weak enforcement regimes. Hodgdon, Tondkar, Harless, and Adhikari (2008) investigate whether analysts' forecasts are affected by the level of disclosure compliance [3]. They find that compliance with the disclosure requirements of IFRS reduces the information asymmetry and enhances the ability of financial analysts to provide more accurate forecasts. This prior literature suggests that dysfunctional reporting incentives could arise under weak enforcement mechanisms.

The corporate governance structure of a firm affects the firm's financial reporting transparency. According to Bhat, Hope, and Kang (2006), corporate governance has a positive effect on the analysts' forecasting performance [24]. Good corporate governance will help analysts forecast earnings more accurately. In this context, if a firm's information environment was already transparent prior to the adoption of IFRS, a transition to IFRS may not further improve the firm's information environment. But, for firms with moderate corporate governance, IFRS adoption could improve their information environment because the IFRS could provide more information. Thus, we predict that firms with moderate corporate governance will benefit from IFRS adoption. In comparison, for firms with weak corporate governance, the beneficial effects of IFRS adoption would be limited because these firms may not implement IFRS properly due to their weakness in corporate governance. Thus, we posit that the beneficial effects of IFRS adoption will depend on the strength of corporate governance prior to 
IFRS adoption. In this context, we predict that the effect of IFRS adoption will differ depending on the firms' prior corporate governance structure.

Hypothesis 2. The effect of IFRS adoption will differ with the firm's prior corporate governance structure.

\section{Research Design}

First, we examine the effect of IFRS adoption by comparing analysts' forecasts errors between the pre- and post-IFRS periods. To test Hypothesis 1, we employ the following model:

$$
\begin{gathered}
\text { FEit }=\beta 0+\beta 1 \text { IFRSD }+\beta 2 \text { SIZEit }+\beta 3 \text { HORIZONit }+\beta 4 \text { LOSSit }+\beta 5 \text { FOLLOWINGit }+ \\
\text { INDUSTRY FIXED EFFECT }+\varepsilon i t
\end{gathered}
$$

where

- Dependent Variable

$\mathrm{FE}_{\mathrm{it}}$ : Forecast error of firm $i$ in year $t$.

- Key Variables

IFRSD: Indicator variable that takes a value of 1 in the post-IFRS period.

- Control Variables

$\mathrm{SIZE}_{\mathrm{it}}$ : The size of the firm, measured by the logarithm of total assets.

HORIZON ${ }_{\mathrm{it}}$ : The number of days between the consensus forecast date and the fiscal year-end date.

LOSS $_{\text {it }}$ : Indicator variable that takes a value of 1 if firm $i$ reports a loss.

FOLLOWING $\mathrm{it}_{\mathrm{it}}$ : The number of analysts that follow firm $i$ in year $t$.

Second, we examine whether the corporate governance influences the effect of IFRS adoption. To measure the corporate governance structure, we use the KCGI that is released by KCGS. In the KCGI, there are 5 categories; Shareholder's right, Board of Directors, Disclosure, Audit Committee, and Ownership Parity. We classify the firms by ranking of the total scores of KCGI. Then, we divide our sample as a quartile group. First quartile group is classified as "High", second and third quartile group are classified as "Middle" and fourth quartile group is classified as "Low". We use both total scores of KCGI and each score of 5 categories. To test Hypothesis 2, we examine the effect of IFRS adoption on analysts' forecast error based on the level of the firms' corporate governance structure with model (2).

$$
\begin{gathered}
\text { FEit }=\beta 0+\beta 1 \text { IFRSD }+\beta 2 \text { SIZEit }+\beta 3 \text { HORIZONit }+\beta 4 \text { LOSSit }+\beta 5 \text { FOLLOWINGit } \\
+\beta 6 \text { Ch_CGit }+ \text { INDUSTRY FIXED EFFECT }+\varepsilon i t
\end{gathered}
$$

where

Ch_CG ${ }_{\text {it }}$ The change of the corporate governance score between the pre- and post-IFRS period.

We measure forecast error $\left(\mathrm{FE}_{\mathrm{it}}\right)$ as the absolute difference between actual earnings and consensus forecast, deflated by stock price at the end of the fiscal year. Our main variable of interest is IFRSD, an indicator variable for the post-IFRS period. If IFRS adoption improves the information environment that analysts face, we expect a negative coefficient on forecast error $\left(\mathrm{FE}_{\mathrm{it}}\right)$ that is $\beta 1<0$. The prior literature on analyst forecasts suggests that analysts' forecast errors are affected by firm-specific factors $[9,25,26]$. SIZEit, HORIZONit, LOSSit, FOLLOWINGit, and Ch_CGit are our control variables. SIZEit is firm size, measured by the logarithm of total assets. If analysts encounter more difficulties when they cover larger firms, the coefficient on SIZE $_{i t}$ will be positive. HORIZON ${ }_{i t}$ is forecast horizon, measured by the number of days between the forecast date and the fiscal year-end date. We expect a positive sign. LOSSit is an indicator variable that takes a value of one if the firm reports a negative income. Analysts are likely to face more difficulties when they forecast financially distressed firms. 


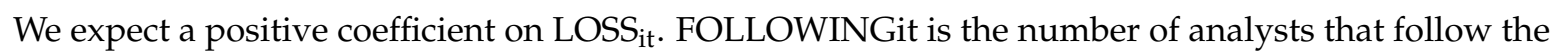
firm. If the degree of information asymmetry is lower for firms with more analysts following, we expect a negative sign. Ch_CGit is the change in the corporate governance score between pre- and post-IFRS period. If there was an improvement in corporate governance in the post-IFRS period, Ch_CGit will be negative. If the firms' corporate governance has improved in the post-IFRS period, the information environment would be more transparent. Therefore, we expect a positive coefficient on Ch_CGit. We include industry dummies to control for the potential industry effect.

\section{Sample and Descriptive Statistics}

\subsection{Sample}

We conducted our tests using a sample of Korean companies over the period from 2007 to 2012. We obtained annual financial data from TS2000 and one-year ahead annual earnings per share forecasts from the I/B/E/S International Summary file. We used KCGI as a proxy of corporate governance structure. KCGI is released by the KCGS to assess the firms' corporate governance structure. KCGI consists of 5 categories: Shareholder's right, Board of Directors, Disclosure, Audit Committee, and Ownership parity. We identify Korean companies by checking that the first two characters of SEDOL is "FK" and the reporting currency is "KRW". Following Clement (1999), we ensure that earnings forecasts are not issued no earlier than 1 year before the fiscal year-end [25]. We also exclude forecasts that are released after actual earnings announcement dates or 3 months after fiscal year end. We use actual reported values that I/B/E/S provides in order to ensure the comparability of actual values and forecast values. We control for the influence of extreme observations by winsorizing dependent and independent variables at the $1 \%$ and $99 \%$ levels.

Table 1 presents sample selection criteria. We identify 644,997 earnings forecasts for Korean firms on the I/B/E/S. There are 154,749 one-year ahead earnings forecasts. We restrict our analysis to firms with a December fiscal year-end, and eliminate earnings forecasts without actual reported earnings data (5360), without stale and inactive forecast (931), without prior stock price (1196), and missing industry classification (46). We require our sample firms to have forecasts both in the preand post-IFRS period. We define pre-IFRS period as the period before the firms adopt IFRS; normally the pre-IFRS period is from 2007 to 2010 in our sample. The post-IFRS period is the period after the firms adopted IFRS; some voluntary firms have 2010, 2011, and 2012 as the post-IFRS period while mandatory firms have 2011 and 2012 as post-IFRS period. We use the first consensus forecasts and it yields 2566 forecasts. We impose a last condition that the firms have been covered by KCGS, so our final sample consists of 1677 firm-year-months of earnings forecast observations from 2007 to 2012.

Table 1. Sample selection criteria.

\begin{tabular}{cc}
\hline Data & Number of Forecasts \\
\hline Earnings per share forecast of Korean companies & 644,997 \\
\hline 1-year ahead annual forecasts & 154,749 \\
\hline Fiscal-ended month: December during 2007 to 2012 & 41,204 \\
\hline Less & \\
\hline Missing actual value & $(5360)$ \\
\hline Adjustment for 12months & $(931)$ \\
\hline Missing prior stock price & $(1196)$ \\
\hline Missing industry classification data & $(46)$ \\
\hline
\end{tabular}


Table 1. Cont.

\begin{tabular}{cc}
\hline Data & Number of Forecasts \\
\hline Total & 33,671 \\
\hline $\begin{array}{c}\text { Existing in both pre- and post-International Financial } \\
\text { Reporting Standards (IFRS) period }\end{array}$ & 26,559 \\
\hline First forecast of the sample & 2566 \\
\hline $\begin{array}{c}\text { Final sample with the Korea Corporate Governance } \\
\text { Stock Price Index (KCGI) }\end{array}$ & 1677 \\
\hline
\end{tabular}

\subsection{Descriptive Statistics}

Table 2 provides descriptive statistics for the variables used in regression analysis. Panel A of Table 2 reveals that the average analysts' forecast error is 0.075 . There are, on average, 10 analysts following the firm, and 10\% of our sample firms have negative earnings. Panel B of Table 2 is correlations among the variables. Correlations among the variables are relatively low; this indicates multicollinearity is unlikely to be an issue with our analysis.

Table 2. Summary statistics.

Panel A: Summary statistics for variables used in regression analysis.

\begin{tabular}{cccccc}
\hline Variable & $\mathbf{N}$ & Mean & Standard Deviation & Min & Max \\
\hline ABSFE & 1677 & 0.075 & 0.129 & 0 & 0.851 \\
\hline IFRSD & 1677 & 0.396 & 0.489 & 0 & 1 \\
\hline SIZE & 1677 & 21.5 & 1.72 & 17.36 & 25.74 \\
\hline HORIZON & 1677 & 267 & 20 & -47 & 345 \\
\hline LOSS & 1677 & 0.100 & 0.300 & 0 & 1 \\
\hline FOLLOWING & 1677 & 9.01 & 10.27 & 1 & 46 \\
\hline Ch_CG & 1677 & 0.167 & 0.203 & -0.308 & 0.555 \\
\hline
\end{tabular}

Panel B: Pearson correlation matrix with $p$-values in parentheses.

\begin{tabular}{cccccc}
\hline Variable & ABSFE & IFRSD & SIZE & HORIZON & LOSS \\
\hline \multirow{2}{*}{ IFRSD } & -0.008 & & & & \\
& $(0.755)$ & & & & \\
& 0.002 & 0.072 & & & \\
SIZE & $(0.920)$ & $(0.003)$ & & & \\
& 0.007 & 0.112 & 0.224 & & \\
HORIZON & $(0.783)$ & $(0.000)$ & $(0.000)$ & 0.048 & \\
& 0.498 & 0.057 & 0.044 & $(0.048)$ & \\
\hline \multirow{2}{*}{ LOSS } & $(0.000)$ & $(0.021)$ & $(0.074)$ & 0.394 \\
& -0.126 & 0.033 & 0.444 & 0.296 & $(0.000)$ \\
\hline \multirow{2}{*}{ FOLLOWING } & $(0.000)$ & $(0.181)$ & $(0.000)$ & $(0.000)$ & \\
&
\end{tabular}

Note. ABSFE is the absolute value of analysts' forecast errors, measured by the difference between analysts' earnings forecast and actual value, deflated by the stock price. IFRSD is an indicator variable for the post-IFRS period. SIZE is a measure of a firm's size, measured by the logarithm of total assets. HORIZON is forecast horizon, measured by the number of days between the forecast date and the fiscal year-end date. LOSS is an indicator variable that takes a value of one if the firm report a negative income. FOLLOWING is the number of analysts that follow the firm. Ch_CG is the change in the corporate governance score between the pre- and post-IFRS period. 
Table 3 presents the mean differences of analysts' forecast error in the pre- and post- IFRS period according to the corporate governance level in the pre-IFRS period. To measure the corporate governance level prior to IFRS adoption, we use the KCGI score in 2009. Then, we divide our sample into quartile groups. We label the first quartile group as "strong", the second and third quartile groups as "moderate" and the fourth quartile group as "weak".

Table 3. Mean differences of analysts' forecast error in the pre- and post-IFRS period according to the corporate governance structure level.

\begin{tabular}{ccccc}
\hline \multicolumn{5}{c}{ Panel A. Firms with Strong Corporate Governance } \\
\hline & Pre-IFRS & Post-IFRS & Change & Significance \\
\hline ABSFE & 0.046 & 0.050 & 0.000 & $<0.01$ \\
SIZE & 23.01 & 23.28 & 0.276 & 0.6692 \\
HORIZON & 266.20 & 307.30 & 41.14 & $<0.01$ \\
LOSS & 0.08 & 0.09 & 0.013 & 0.2945 \\
FOLLOWING & 13.48 & 15.72 & 2.241 & 0.1130 \\
\hline \multicolumn{5}{c}{ Panel B. Firms with Moderate Corporate Governance } \\
\hline Pre-IFRS & Post-IFRS & Change & Significance \\
\hline ABSFE & 0.080 & 0.070 & 0.016 & $<0.01$ \\
SIZE & 21.37 & 21.61 & 0.241 & 0.3449 \\
HORIZON & 265.20 & 280.20 & 14.99 & $<0.01$ \\
LOSS & 0.10 & 0.13 & 0.033 & 0.1444 \\
FOLLOWING & 8.63 & 9.15 & 0.518 & $<0.01$ \\
\hline \multicolumn{5}{c}{ Panel C. Firms with Weak Corporate Governance } \\
\hline ABSFE & 0.084 & 0.100 & -0.016 & 0.9403 \\
SIZE & 19.78 & 20.20 & 0.428 & 0.9196 \\
HORIZON & 246.30 & 241.50 & -4.77 & $<0.01$ \\
LOSS & 0.08 & 0.13 & 0.057 & $<0.01$ \\
FOLLOWING & 3.96 & 4.01 & 0.052 & 0.3124 \\
\hline
\end{tabular}

For firms with the "moderate" corporate governance, there was a drop in the mean absolute analyst' forecast error after IFRS adoption; but, such a drop was not observed for firms with "strong" or "weak" corporate governance. This result indicates that corporate governance matters when we examine the benefit of IFRS adoption.

\section{Results}

The main purpose of this paper is to examine whether IFRS adoption improves information environment. Also, we investigate whether the effect of IFRS adoption varies according to the strength of corporate governance prior to IFRS adoption. We use the KCGI as a proxy for corporate governance. We examine change in analysts' earnings forecast errors to infer change in the information environment.

\subsection{Impact of IFRS Adoption on the Analysts' Earnings Forecast}

Table 4 presents the regression result for the impact of IFRS adoption on analysts' forecast errors. Consistent with prior studies, we find that analysts' forecast errors increase when they forecast financially distressed firms and less followed firms by peer analysts. Regarding our main variable of interest (IFRSD), the coefficient estimate on IFRSD is significantly negative at the $10 \%$ level for the full sample. This indicates that IFRS significantly lowers the general analysts' forecast errors in the post-IFRS period. That is, IFRS adoption enhances the information environment of analysts. 
Table 4. Effect of IFRS adoption on analysts' information environment.

\begin{tabular}{cccc}
\hline Variable & $\begin{array}{c}\text { Predicted Sign } \\
\text { (Pred.Sign) }\end{array}$ & $\begin{array}{c}\text { Coefficient } \\
\text { (Coeff.) }\end{array}$ & $\begin{array}{c}\text { t-statistics } \\
\text { (t-stat.) }\end{array}$ \\
\hline Intercept & $?$ & 0.045 & 0.50 \\
IFRSD & - & $-0.008^{*}$ & -1.74 \\
SIZE & - & 0.002 & 0.17 \\
HORIZON & + & $0.000^{* *}$ & 2.09 \\
LOSS & + & $0.173^{* * *}$ & 23.39 \\
FOLLOWING & - & $-0.001^{* * *}$ & -4.81 \\
Industry Fixed & & Yes & \\
Adjusted R & & 30.62 & \\
No. of observations & & 1677 & \\
\hline
\end{tabular}

Note. See Table 2 for variable definitions. ${ }^{* * *},{ }^{* *}$, and ${ }^{*}$ indicate significance at the $1 \%, 5 \%$, and $10 \%$ levels or better, respectively.

\subsection{Impact of IFRS Adoption on the Analysts' Earnings Forecast Regarding Corporate Governance Structure}

Table 5 presents the regression results of the impact of IFRS adoption on analysts' forecast errors with different levels of corporate governance strength. In column (1), we cannot find a significant result for the relation between IFRS adoption and analysts' forecast errors (coefficient $=0.004$, t-statistic $=0.36$ ). It indicates that analysts were not able to forecast earnings more accurately in the post-IFRS perios when they followed firms with weak corporate governance.

Table 5. Effect of IFRS adoption on analysts' information environment-varying the firms' corporate governance.

\begin{tabular}{|c|c|c|c|c|c|c|c|}
\hline \multirow[t]{2}{*}{ Variable } & \multirow{2}{*}{$\begin{array}{c}\text { Corporate Governance } \\
\text { Pred.Sign }\end{array}$} & \multicolumn{2}{|c|}{ Weak } & \multicolumn{2}{|c|}{ Moderate } & \multicolumn{2}{|c|}{ Strong } \\
\hline & & Coeff. & t-stat. & Coeff. & t-stat. & Coeff. & t-stat. \\
\hline Intercept & $?$ & -0.023 & -0.15 & -0.092 & -1.15 & 0.032 & 0.43 \\
\hline IFRSD & - & 0.004 & 0.36 & $-0.017 * * *$ & -3.04 & -0.003 & -0.45 \\
\hline SIZE & + & 0.000 & 0.01 & $0.007^{* * *}$ & 2.74 & -0.001 & -0.19 \\
\hline HORIZON & + & $0.000^{* *}$ & 2.13 & 0.000 & 0.65 & 0.000 & 1.25 \\
\hline LOSS & + & $0.206^{* * *}$ & 10.72 & $0.155^{* * *}$ & 16.52 & $0.109^{* * *}$ & 11.16 \\
\hline FOLLOWING & - & $-0.003^{* *}$ & -2.28 & $-0.001^{* * *}$ & -3.80 & -0.000 & -0.64 \\
\hline Ch_CG & + & -0.059 & -1.00 & 0.005 & 0.36 & $0.028^{* *}$ & 2.12 \\
\hline Industry Fixed & & \multicolumn{2}{|c|}{ Yes } & \multicolumn{2}{|c|}{ Yes } & \multicolumn{2}{|c|}{ Yes } \\
\hline Adjusted $R^{2}$ & & \multicolumn{2}{|c|}{30.53} & \multicolumn{2}{|c|}{35.04} & \multicolumn{2}{|c|}{31.82} \\
\hline No. of obs. & & \multicolumn{2}{|c|}{417} & \multicolumn{2}{|c|}{840} & \multicolumn{2}{|c|}{420} \\
\hline
\end{tabular}

Note. See Table 2 for variable definitions. ${ }^{* * *}$, **, and ${ }^{*}$ indicate significance at the $1 \%, 5 \%$, and $10 \%$ levels or better, respectively.

In column (2), we find that the coefficient on IFRSD, $\beta 1$, is negative and significant (coefficient $=-0.017$, $\mathrm{t}$-statistic $=-3.04$ ). This indicates that analysts were able to decrease their forecasting errors in the post-IFRS period when they followed firms with moderate corporate governance. In column (3), we observe no significant result for the relation between IFRS adoption and analysts' forecast errors (coefficient $=-0.003$, $\mathrm{t}$-statistic $=-0.45$ ). These findings suggest that IFRS adoption does not affect the information environment of firms with strong or weak corporate governance.

These findings are consistent with the prediction that the transition to higher-quality accounting standards would not necessarily improve the information environment of a firm if the firm was already transparent. Also, it indicates that weak corporate governance could compromise potential benefits of IFRS adoption. Our findings indicate that the effect of IFRS adoption on improving the financial information environment is effective for firms with moderate corporate governance. 


\subsection{Robustness Tests}

To assess the robustness of our results, we repeat our analyses using two alternative size proxies. Following Dang, Li, and Yang (2018), we use the sales and market value of equity as alternative proxies. The sample size slightly reduced due to the further data requirements for non-zero sales and the market capitalization [27].

Table 6 presents the results using sales as a proxy for firm size. We find that the results are consistent with those in Tables 4 and 5 . We have similar results when we use the market capitalization as a proxy for firm size in Table 7. For example, Panel A of Table 7 shows that the coefficient on IFRSD is significantly negative (coefficient $=-0.008$, $t$-statistic $=-1.75$ ). Panel $\mathrm{B}$ of Table 7 shows that the coefficient on IFRSD is significant only for firms with moderate corporate governance. Collectively, the findings in Tables 6 and 7 support that the beneficial effect of IFRS adoption is effective for firms with moderate corporate governance regardless of the employed proxy for firm size.

Table 6. Different measure of firm size: sales.

Panel A: Effect of IFRS adoption on analysts' information environment.

\begin{tabular}{cccc}
\hline Variable & Predicted Sign & Coefficient & t-statistics \\
\hline Intercept & $?$ & 0.017 & 0.44 \\
IFRSD & - & $-0.008^{*}$ & -1.85 \\
SIZE2 & - & -0.000 & -0.09 \\
HORIZON & + & $0.000^{*}$ & 1.85 \\
LOSS & + & $0.173^{* * *}$ & 23.04 \\
FOLLOWING & - & $-0.001^{* * *}$ & -4.93 \\
Industry Fixed & & Yes & \\
Adjusted $R^{2}$ & & 30.65 & \\
No. of observations & & 1579 & \\
\hline
\end{tabular}

Note. See Table 2 for variable definitions. ${ }^{* * *}, * *$, and ${ }^{*}$ indicate significance at the $1 \%, 5 \%$, and $10 \%$ levels or better, respectively.

Panel B: Effect of IFRS adoption on analysts' information environment-varying the firms' corporate governance structure.

\begin{tabular}{cccccccc}
\hline Variable & Corporate Governance & \multicolumn{2}{c}{ Weak } & \multicolumn{2}{c}{ Moderate } & \multicolumn{2}{c}{ Strong } \\
\hline & Pred.Sign & Coeff. & t-stat. & Coeff. & t-stat. & Coeff. & t-stat. \\
\hline Intercept & $?$ & $-0.023^{*}$ & -1.69 & -0.067 & -1.10 & 0.032 & 0.51 \\
IFRSD & - & -0.004 & -0.35 & $-0.017^{* * *}$ & -2.76 & -0.002 & -0.31 \\
SIZE2 & + & $0.012^{*}$ & 1.76 & $0.005^{*}$ & 1.75 & -0.000 & -0.14 \\
HORIZON & + & $0.000^{*}$ & 1.79 & 0.000 & 0.38 & 0.000 & 0.80 \\
LOSS & + & $0.208^{* * *}$ & 10.95 & $0.159 * * *$ & 15.77 & $0.111^{* * *}$ & 11.32 \\
FOLLOWING & - & $-0.003^{* * *}$ & -2.74 & $-0.001^{* * *}$ & -3.54 & -0.000 & -0.53 \\
Ch_CG & + & 0.019 & 0.29 & 0.003 & 0.19 & 0.015 & 1.01 \\
Industry Fixed & & \multicolumn{2}{c}{ Yes } & \multicolumn{2}{c}{ Yes } & \multicolumn{2}{c}{ Yes } \\
Adjusted $R^{2}$ & & \multicolumn{2}{c}{31.02} & \multicolumn{2}{c}{791} & & 33.68 \\
No. of obs. & & \multicolumn{2}{c}{412} & & & 376 \\
\hline
\end{tabular}

Note. See Table 2 for variable definitions. ${ }^{* * *},{ }^{* *}$, and ${ }^{*}$ indicate significance at the $1 \%, 5 \%$, and $10 \%$ levels or better, respectively. 
Table 7. Different measure of firm size: market value of equity.

Panel A: Effect of IFRS adoption on analysts' information environment.

\begin{tabular}{cccc}
\hline Variable & Predicted Sign & Coefficient & t-statistics \\
\hline Intercept & $?$ & $0.138^{* * *}$ & 5.32 \\
IFRSD & - & $-0.008^{*}$ & -1.75 \\
SIZE3 & - & $-0.010^{* * *}$ & -5.75 \\
HORIZON & + & $0.000^{* * *}$ & 2.64 \\
LOSS & + & $0.167^{* * *}$ & 22.41 \\
FOLLOWING & - & $-0.001^{* *}$ & -2.17 \\
Industry Fixed & & Yes & \\
Adjusted $R^{2}$ & & 32.08 & \\
No. of observations & & 1579 &
\end{tabular}

Note. See Table 2 for variable definitions. ${ }^{* * *},{ }^{* *}$, and ${ }^{*}$ indicate significance at the $1 \%, 5 \%$, and $10 \%$ levels or better, respectively.

Panel B: Effect of IFRS adoption on analysts' information environment-varying the firms' corporate governance structure.

\begin{tabular}{cccccccc}
\hline Variable & Corporate Governance & \multicolumn{2}{c}{ Weak } & \multicolumn{2}{c}{ Moderate } & \multicolumn{2}{c}{ Strong } \\
\hline & Pred.Sign & Coeff. & t-stat. & Coeff. & t-stat. & Coeff. & t-stat. \\
\hline Intercept & $?$ & $0.177^{*}$ & 1.74 & 0.126 & 3.34 & $0.105^{*}$ & 1.84 \\
IFRSD & - & 0.008 & 0.72 & $-0.014^{* *}$ & -2.34 & -0.003 & -0.50 \\
SIZE3 & + & $-0.015^{* *}$ & -2.16 & $-0.007^{* * *}$ & -2.87 & -0.005 & -1.51 \\
HORIZON & + & $0.000^{* *}$ & 2.39 & 0.000 & 0.71 & 0.000 & 0.93 \\
LOSS & + & $0.201^{* * *}$ & 10.44 & $0.152^{* * *}$ & 14.78 & $0.111^{* * *}$ & 11.32 \\
FOLLOWING & - & -0.001 & -1.09 & $-0.001^{*}$ & -1.75 & -0.000 & -0.32 \\
Ch_CG & + & -0.042 & -0.63 & $0.029^{*}$ & 1.87 & 0.008 & 0.50 \\
Industry Fixed & & \multicolumn{2}{c}{ Yes } & \multicolumn{2}{c}{ Yes } & \multicolumn{2}{c}{ Yes } \\
Adjusted $R^{2}$ & & \multicolumn{2}{c}{31.29} & \multicolumn{2}{c}{791} & & 34.09 \\
No. of obs. & & \multicolumn{2}{c}{412} & & & 376 \\
\hline
\end{tabular}

Note. See Table 2 for variable definitions. ${ }^{* * *},{ }^{* *}$, and ${ }^{*}$ indicate significance at the $1 \%, 5 \%$, and $10 \%$ levels or better, respectively.

\section{Conclusions}

The overall prospect of IFRS adoption is that IFRS will improve information environments and convergence in financial reporting standards across countries. The effect of IFRS adoption is questioned because the effect could vary by firm-specific or country-specific factors. This study investigates whether IFRS adoption improves the information environment and whether the effect of IFRS adoption varies with firm-specific factors, namely the corporate governance in Korea. Given adoption of the IFRS, the financial reporting environment has been changing.

Using the Korea Corporate Governance Stock Price Index as a proxy for corporate governance, we find that the effect of IFRS adoption varies depending on a firm's corporate governance in the pre-IFRS period. Consistent with our hypothesis, we find that analysts' forecast errors significantly decrease after IFRS adoption. Furthermore, we find that the beneficial effect of IFRS adoption is not universal. The beneficial effect of IFRS is observed for firms with moderate corporate governance, but not for firms with strong or weak corporate governance. We interpret our findings such that firms with strong corporate governance already had a transparent information system prior to IFRS adoption and firms with weak corporate governance failed to implement IFRS properly.

Author Contributions: J.C. contributed to design the theoretical framework and undertake the primary research. J.P. and K.H. were in charge of research method and statistical analysis. J.C., J.P. and K.H. discussed the results and were responsible for writing the manuscript.

Funding: Pae acknowledges the financial support from the Korea University Business School Research Grant.

Conflicts of Interest: The authors declare no conflict of interest. 


\section{References}

1. Barth, M.; Landsman, W.; Lang, M. International accounting standards and accounting quality. J. Account. Res. 2008, 46, 467-498. [CrossRef]

2. Quigley, J. Deloitte and Touche World Meeting, Berlin, Germany. Available online: http:/ /www.iasplus. com/en/binary/resource/0706quigley.pdf (accessed on 10 June 2012).

3. Hodgdon, C.; Tondkar, R.H.; Harless, D.W.; Adhikari, A. Compliance with IFRS disclosure requirements and individual analysts' forecast errors. J. Int. Account. Audit. Tax. 2008, 17, 1-13. [CrossRef]

4. Kvaal, E.; Nobes, C.W. International differences in IFRS policy choice. Account. Bus. Res. 2010, 40, $173-187$. [CrossRef]

5. Ball, R. International Financial Reporting Standards (IFRS): Pros and cons for investors. Account. Bus. Res. 2006, 36, 5-27. [CrossRef]

6. Yip, R.W.; Young, D. Does mandatory IFRS adoption improve information comparability? Account. Rev. 2012, 87, 1767-1789. [CrossRef]

7. Daske, H.; Hail, L.; Leuz, C.; Verdi, R. Mandatory IFRS reporting around the world: Early evidence on the economic consequences. J. Account. Res. 2008, 46, 1085-1142.

8. Armstrong, C.S.; Barth, M.E.; Jagolinzer, A.D.; Riedl, E.J. Market reaction to the adoption of IFRS in Europe. Account. Rev. 2010, 85, 31-61. [CrossRef]

9. Byard, D.; Li, Y.; Yu, Y. The effect of mandated IFRS adoption on analysts' forecast errors. J. Account. Res. 2011, 49, 69-96. [CrossRef]

10. DeFond, M.; Hu, X.; Hung, M.; Li, S. The impact of mandatory IFRS adoption on foreign mutual fund ownership: The role of comparability. J. Account. Econ. 2011, 51, 240-258. [CrossRef]

11. Pae, J.; Thornton, D.; Welker, M. Agency cost reduction associated with EU financial reporting reform. J. Int. Account. Res. 2008, 7, 51-75. [CrossRef]

12. Ashbaugh, H.; Pincus, M. Domestic accounting standards, international accounting standards, and the predictability of earnings. J. Account. Res. 2001, 39, 417-434. [CrossRef]

13. Chen, H.; Tang, Q.; Jiang, Y.; Lin, Z. The role of international financial reporting standards in accounting quality: Evidence from the European Union. J. Int. Financ. Manag, Account. 2010, 21, 220-278. [CrossRef]

14. Bae, K.H.; Tan, H.; Welker, M. International GAAP differences: The impact on foreign analysts. Account. Rev. 2008, 83, 593-628. [CrossRef]

15. Jiao, T.; Koning, M.; Mertens, G.; Roosenboom, P. Mandatory IFRS adoption and its impact on analysts' forecasts. Int. Rev. Financ. Anal. 2012, 21, 56-63. [CrossRef]

16. Horton, J.; Serafeim, G.; Serafeim, I. Does mandatory IFRS adoption improve the information environment? Contemp. Account. Res. 2013, 30, 388-423. [CrossRef]

17. Stiglitz, J. The Role of International Financial Institutions in the Current Global Economy, Address to the Chicago Council on Foreign Relations; The World Bank: Washington, DC, USA, 27 February 1998.

18. Harvey, C.; Roper, A. The Asian bet. In Financial Markets and Development: The Crisis in Emerging Markets; Harwood, A., Litan, R., Pomerleano, M., Eds.; Brookings Institution: Washington, DC, USA, 1999; pp. $29-115$.

19. La Porta, R.; Lopez-De-Silanes, F.; Shleifer, A.; Vishny, R. Investor protection and corporate governance. J. Financ. Econ. 2000, 58, 3-27. [CrossRef]

20. Jonson, S.; La Porta, R.; Lopez-De-Silanes, F.; Shleifer, A. Tunneling. Am. Econ. Rev. Pap. Proc. 2000, 90, $22-27$. [CrossRef]

21. Daske, H. Economic Benefits of Adopting IFRS or US-GAAP-Have the Expected Cost of Equity Capital Really Decreased? J. Bus. Finan. Account. 2006, 33, 329-373. [CrossRef]

22. Ernstberger, J.; Krotter, S.; Stadler, C. Analysts' forecast accuracy in Germany: The effect of different accounting principles and changes of accounting principles. Bus. Res. 2008, 1, 26-53. [CrossRef]

23. Cotter, J.; Tarca, A.; Wee, M. IFRS adoption and analysts' earnings forecasts: Australian evidence. Account. Finan. 2012, 52, 395-419. [CrossRef]

24. Bhat, G.; Hope, O.K.; Kang, T. Does corporate governance transparency affect the accuracy of analyst forecasts? Account. Financ. 2006, 46, 715-732. [CrossRef]

25. Clement, M. Analysts forecast accuracy: Do ability, resources and portfolio complexity matter? J. Account. Econ. 1999, 27, 285-303. [CrossRef] 
26. Duru, A.; Reeb, D.M. International diversification and analysts' forecast accuracy and bias. Account. Rev. 2002, 77, 415-433. [CrossRef]

27. Dang, C.; Li, Z.F.; Yang, C. Measuring firm size in empirical corporate finance. J. Bank. Financ. 2018, 86, 159-176. [CrossRef] 